\title{
Severe case of asbestos-related lung diseases
}

\author{
Pichapong Tunsupon, ${ }^{1}$ Pojchawan Yampikulsakul ${ }^{2}$
}

${ }^{1}$ University at Buffalo, State University of New York at Buffalo, Veteran Hospital, Buffalo, New York, USA ${ }^{2}$ University at Buffalo, State University of New York at Buffalo, Hertel Elmwood Medical Center, Buffalo, New York, USA

\section{Correspondence to} Dr Pichapong Tunsupon, ptunsupon@gmail.com

Accepted 13 January 2016

\section{DESCRIPTION}

A 90-year-old man was referred for evaluation of shortness of breath. He had a significant history of asbestos exposure, dating back to when he removed asbestos insulation from a US Navy ship 60 years earlier. He had quit smoking 30 years prior to presentation. Physical examination was significant for inspiratory crackles. Pulmonary function test revealed moderate restrictive lung disease and severe reduction of diffusing capacity for carbon monoxide, consistent with clinical suspicion of asbestos-related lung disease. We show images of pleural and pulmonary asbestosis, as well as CT of the chest (figures 1 and 2). While bilateral pleural thickening suggested the diagnosis of pleural asbestosis, pleural plaque deposited predominantly within the parietal pleura was a pathognomonic sign of pleural asbestosis. It was a benign condition and did not require treatment. CT of the chest also demonstrated the usual interstitial pneumonitis pattern consistent with the diagnosis of pulmonary asbestosis (figure 2). CT of the chest was more sensitive than chest X-ray to diagnose pulmonary asbestosis. ${ }^{1}$ The presence of pleural plaque differentiated pulmonary asbestosis from other interstitial lung diseases. Most of the patients who developed pulmonary asbestosis were asymptomatic for decades after the initial exposure, whereas other interstitial lung diseases progressed more rapidly. Asbestos exposure increased risk of malignant mesothelioma ${ }^{2}$ and bronchogenic alveolar carcinoma in cigarette smokers approximately 60 times. ${ }^{3}$ There was no specific treatment; nevertheless, smoking cessation, avoidance of asbestos exposure and oxygen supplementation were supportive measures for pulmonary asbestosis. Our patient was referred to a palliative care service for symptomatic treatment of his dyspnoea.

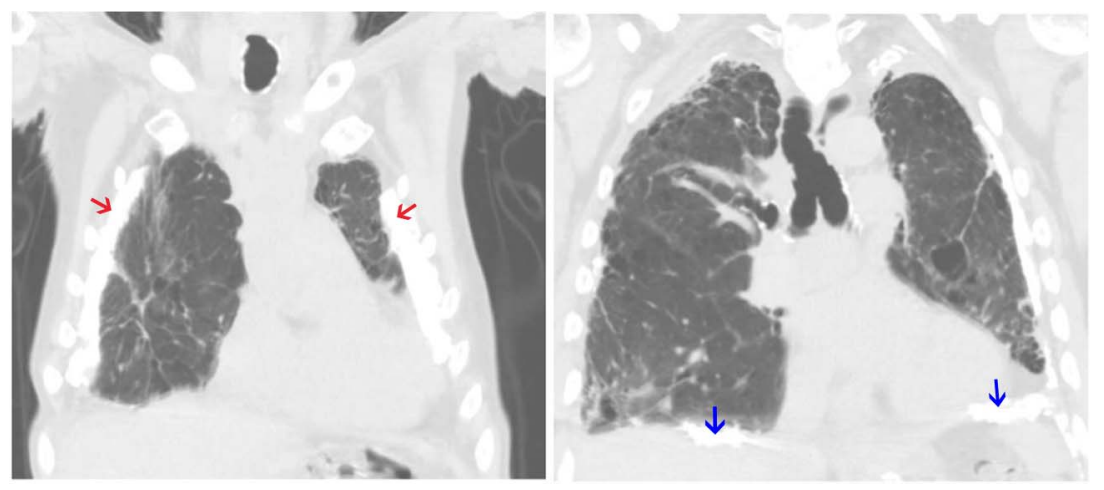

Figure 1 A coronal view of the chest $\mathrm{CT}$ demonstrating calcified pleural plaque deposited symmetrically along the bilateral chest wall (red arrow) and bilateral diaphragmatic pleura (blue arrow).

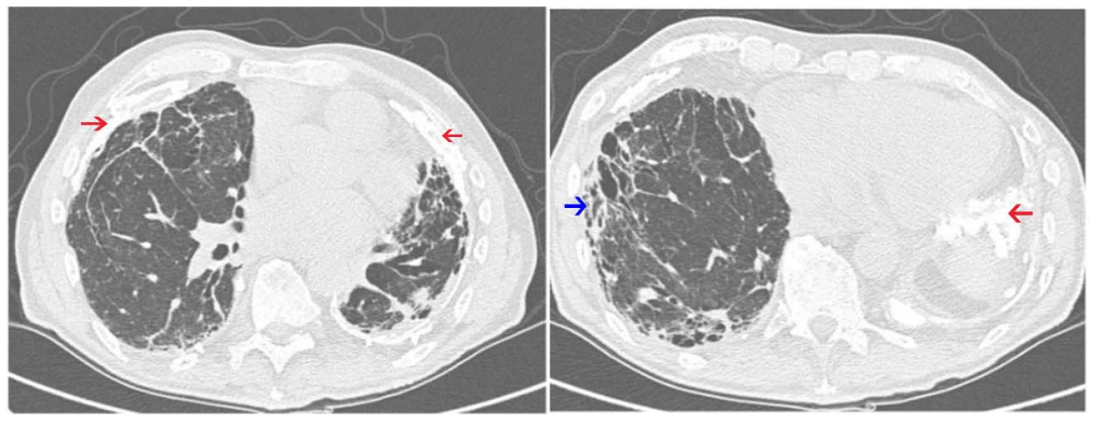

To cite: Tunsupon $P$, Yampikulsakul P. BMJ Case Rep Published online: [please include Day Month Year] doi:10.1136/bcr-2015214189

Figure 2 An axial view of the chest CT demonstrates bilateral pleural thickening and pleural plaque along the chest wall, and dome of the left hemi-diaphragm (red arrow), a pathognomonic sign of pleural asbestosis. Sub-pleural honeycombing and reticulation (blue arrow) seen in the lower lung zones in addition to the presence of pleural plaque confirm the diagnosis of pulmonary asbestosis. 


\section{Learning points}

- Pleural plaque is a pathognomonic sign of pleural asbestosis. The usual interstitial pneumonitis pattern on chest $\mathrm{CT}$ in addition to the presence of pleural plaque confirms the diagnosis of pulmonary asbestosis.

- There is no specific treatment for pleural asbestosis nor for pulmonary asbestosis. Palliative care referral should be considered in patients with severe pulmonary asbestosis.
Competing interests None declared.

Patient consent Obtained.

Provenance and peer review Not commissioned; externally peer reviewed.

\section{REFERENCESZ}

1 Staples CA, Gamsu G, Ray CS, et al. High resolution computed tomography and lung function in asbestos-exposed workers with normal chest radiographs. Am Rev Respir Dis 1989:139:1502-8.

2 Price B, Ware A. Mesothelioma trends in the United States: an update based on surveillance, epidemiology, and end results program data for 1973 through 2003. Am J Epidemiol 2004;159:107-12.

3 Hammond EC, Selikoff IJ, Seidman H. Asbestos exposure, cigarette smoking and death rates. Ann N Y Acad Sci 1979:330:473-90.

Copyright 2016 BMJ Publishing Group. All rights reserved. For permission to reuse any of this content visit http://group.bmj.com/group/rights-licensing/permissions.

BMJ Case Report Fellows may re-use this article for personal use and teaching without any further permission.

Become a Fellow of BMJ Case Reports today and you can:

- Submit as many cases as you like

- Enjoy fast sympathetic peer review and rapid publication of accepted articles

- Access all the published articles

- Re-use any of the published material for personal use and teaching without further permission

For information on Institutional Fellowships contact consortiasales@bmjgroup.com

Visit casereports.bmj.com for more articles like this and to become a Fellow 